\title{
The Determinants of Purchase Decision on Cinema by Intervening Variable of Attitude and Purchase Intention
}

\author{
Amiril Azizah $^{1}$, Ahyar M Diah $^{2}$, Herlina Rahmawati $^{3}$ \\ \{amirilazizah@polnes.ac.id $\left.{ }^{1}\right\}$ \\ Polytechnic state of Samarinda, Indonesia ${ }^{1,2,3}$
}

\begin{abstract}
Business cannot be separated from good service to make customer satisfaction. Thus, the objective of this study is to identify the effect of Service Quality, Social Influence, and social media, as well as Hedonic Value on Purchase Decision through Attitude and Purchase Intention on the Cinema XXI visitors of Big mall Samarinda. This study uses a quantitative approach using path analysis processed with SPSS and Structural Equation Modeling (SEM). The sample of 133 respondents was taken from society in Samarinda. The measurement scale uses a Likert scale with a score of $1-5$. This study also tested the validity and reliability test, then carried out a further test of estimation and structural fit model test. The results are shown that social media and Hedonic Value having a significant impact on attitude and social media. Moreover, Attitude has a significant impact on Purchase Intention; Service Quality. Furthermore, Attitude and Purchase Intention has statistically significantly on Purchase Decision. However, Service Quality has no significant effect on Attitude; Service Quality, Social Influence. Additionally, Hedonic Value has no significant effect on Purchase Intention; Social Influence. Moreover, Hedonic Value has no significant effect on Purchase Decision.
\end{abstract}

Keywords: Service quality, social influence, social media, hedonic value, attitude, purchase intention, purchase decision, cinema XXI

\section{Introduction}

The development for entertainment with all facilities and infrastructure has increased quite rapidly. It is means entertainment services are currently a tool that is needed for every human being because this service is very useful on entertainment to avoid of fatigue experienced from the various activities carried out. Along with the increasing phenomenon of community activity, one of the most popular entertainments is watching movies. There are also various entertainment facilities that exist to entertain yourself, one of which is the cinema or sometimes it is also called the cinema. The problems are:1) Does Service Quality have a significant effect on Attitude on Cinema XXI?;2) Does Service Quality have a significant effect on Purchase Intention on Cinema XXI?;3) Does Service Quality have a significant effect on Purchase Decision for Cinema XXI?;4) Does Social Influence have a significant effect on Attitude for Cinema XXI?;5) Does Social Influence have a significant effect on Purchase Intention for Cinema XXI;6) Does Social Influence have a significant effect on Purchase Decision for Cinema XXI?;7) Does Social Media have a significant effect on Attitude for Cinema XXI?;8) Does Social Media have a 
significant effect on Purchase Intention for Cinema XXI?;9) Does Social Media have a significant effect on Purchase Decision for Cinema XXI?;10) Does Hedonic Value have a significant effect on Attitude on Cinema XXI?;11) Does Hedonic Value have a significant effect on Purchase Intention on Cinema XXI?;12) Does Hedonic Value have a significant effect on Purchase Decision on Cinema XXI?;13) Does Attitude have a significant effect on Purchase Intention for Cinema XXI?;14) Does Attitude have a significant effect on Purchase Decision on Cinema XXI?;15) Does Purchase Intention have a significant effect on Purchase Decision on Cinema XXI?

Kotler and Keller [2] Marketing is no longer a departmental firm that is burdened with a limited number of tasks, it is a company-wide job. It drives the company's vision, mission and strategic planning. Marketing includes decisions such as who the company wants as its customer, which needs to be met, what products and services to offer, what prices to charge, what communications to send and receive, what distribution channels to use and what partnerships to develop.

The service industry is currently a very large economic sector and its growth is very fast. This growth was not only caused by the growth of pre-existing services, but also by the emergence of new types of services, as a result of the demands and developments of the times. The rapid growth of the service business between countries is indicated by the increasing intensity of cross-border marketing and the occurrence of alliances of various service providers in the world. Personal characteristics that influence buyer's decisions include age and stage in the life cycle, occupation and economic circumstances, personality and self-concept as well as lifestyle and values [4].

Service quality refer to the degree of difference between customer expectations and their perceptions or desires. Service quality is defined as the difference between customer expectations and perceptions of the service offered. Crosby, et al. argued that trust and satisfaction as the indicator for the quality of service. Social influence is considered as how other people influence consumers' judgment and decision-making processes. Social influence is defined as a change in an individual's thoughts, feelings, attitudes or behavior that results from communication with other individuals or groups. The term social influence is used here to refer to this phenomenon, that is, extended family members from the reference group influence each other's behavior and experience social pressure to perform certain behaviors.

Attitude is the extent to which a person has favorable or unfavorable evaluations or assessments of the behavior in question. Attitudes represent feelings of liking or disliking someone towards an object. Attitudes as evaluations, emotional feelings, and tendencies of favorable (beneficial) and opposite (unfavorable) actions, and last a long time from a person to an object or idea [1]. Attitude includes observed consequences related to behavior. Attitudes are psychological emotions that are routed through consumer evaluations and, if positive, behavioral intentions tend to be more positive.

Purchase Intention is the tendency of a customer to buy a brand or take action related to a purchase as measured by the likelihood of making a purchase. Purchase interest is a stage that is carried out by consumers before planning to buy a product [1]. Schiffman and Kanuk state that buying interest is a model of a person's attitude towards a particular product, service or brand, in other words it can assess the likelihood of consumers buying a product, and the higher the buying interest, the higher the consumer's desire to buy a product.

The stage in the buyer's decision-making process where consumers actually buy [1]. A decision involves a choice between two or more alternative actions or behaviors, so that a purchase decision is an action taken by consumers in purchasing a product to get the desired 
product through alternative choices regarding product choices, supplier choices, choices. brand, and timing options, leading to a buying decision.

\section{Method}

The data were collected from customer trough a questioner. The structure of this study was developed using a measurement scale adopted from previous studies. All of them approved to use a likert scale of 1-5 with criteria $1=$ strongly disagree, $5=$ strongly agree. Data were collected from customer cinema XXI in Samarinda through a questionnaire with 150 samples. The number of variables is 7 variables consisting of 4 exogenous variables, 2 intervening variables, and 1 endogenous variable with 30 indicators.

\section{Results and Discussion}

The test results of goodness of fit shown that six fit criteria and three criteria not fit from the total of nine criteria as shown in Table 1. This indicated that the model in this research was good and qualified to the hypothesis.

Table 1. The test results of Goodness of fit Overall model

\begin{tabular}{llll}
\hline Goodness of Fit index & Cut of Value & Results & Information \\
\hline Chi-square & small & 434.281 & Not Fit \\
Significancy Probability & $\geq 0,05$ & 0.060 & Fit \\
RMR & $\leq 0,10$ & 0.075 & Fit \\
RMSEA & $\leq 0,08$ & 0.029 & Fit \\
GFI & $\geq 0,90$ & 0.820 & Not fit \\
AGFI & $\geq 0,90$ & 0.785 & Not fit \\
CMIN/ DF & $\leq 2,00$ & 1.114 & Fit \\
TLI & $\geq 0,90$ & 0.962 & Fit \\
CFI & $\geq 0,95$ & 0.966 & Fit \\
\hline
\end{tabular}

The hypothesis test results using the AMOS program shown in Table 2. It is shown that the overall 15 hypotheses have different result. Eight variables are significant and seven variables are not significant.

Table 1. The hypothesis result test

\begin{tabular}{lllll}
\hline Variables & $\begin{array}{l}\text { Standardised } \\
\text { coefficient }\end{array}$ & $\begin{array}{l}\text { C.R (Critical } \\
\text { Ratio) }\end{array}$ & Probability & Information \\
\hline SQ $\rightarrow$ Att & 0.107 & 1.121 & 0,262 & Not Significant \\
SQ $\rightarrow$ PI & -0.069 & -0.629 & 0.529 & Not Significant \\
SQ $\rightarrow$ PD & -0.194 & -2.089 & 0.037 & Significant \\
SI $\rightarrow$ Att & 0.215 & 2.076 & 0.038 & Significant \\
SI $\rightarrow$ PI & -0.057 & -0.533 & 0.594 & Not Significant \\
SI $\rightarrow$ PD & 0.016 & 0.196 & 0,845 & Not Significant \\
SM $\rightarrow$ Att & 0.282 & 2.076 & 0.045 & Significant \\
SM $\rightarrow$ PI & 0.376 & 2.161 & 0.031 & Significant \\
\hline
\end{tabular}




\begin{tabular}{lllll}
\hline Variables & $\begin{array}{l}\text { Standardised } \\
\text { coefficient }\end{array}$ & $\begin{array}{l}\text { C.R }(\text { Critical } \\
\text { Ratio) }\end{array}$ & Probability & Information \\
\hline SM $\rightarrow$ PD & -0.025 & -0.190 & 0.849 & Not Significant \\
HV $\rightarrow$ Att & 0.428 & 3.311 & $* * *$ & Significant \\
HV $\rightarrow$ PI & 0.102 & 0.729 & 0.466 & Not Significant \\
HV $\rightarrow$ PD & -0.099 & -0.927 & 0.354 & Not Significant \\
Att $\rightarrow$ PI & 0.767 & 2.349 & 0.019 & Significant \\
Att $\rightarrow$ PD & 0.685 & 2.031 & 0.042 & Significant \\
PI $\rightarrow$ PD & 0.496 & 2.365 & 0.018 & Significant \\
\hline
\end{tabular}

The hypothesis test using AMOS, the analysis results part as shown in Figure 1. Based on the results of the calculation of the path coefficient between Service Quality and Purchase Intention, it shows an insignificant influence with a negative direction of -0.069 , which means that the level of closeness or strength of the relationship between Service Quality and Purchase Intention variables is $7 \%$. Based on the statistical test results, the value of the Critical Ratio (CR) variable of Service Quality to Purchase Intention is -0.629 , which is smaller than the critical value of \pm 1.96 which is determined from the t table if a study uses more than 100 respondents. The insignificant results can also be seen from the probability value. (p-value) of 0.529 which is greater than the error rate $(\alpha)$ which is set at $5 \%$ and 0.05 . This shows that Service Quality has a negative and insignificant effect on Purchase Intention for Cinema XXI. It is means that interest in watching Cinema XXI is not influenced by the quality of service provided by Cinema XXI.

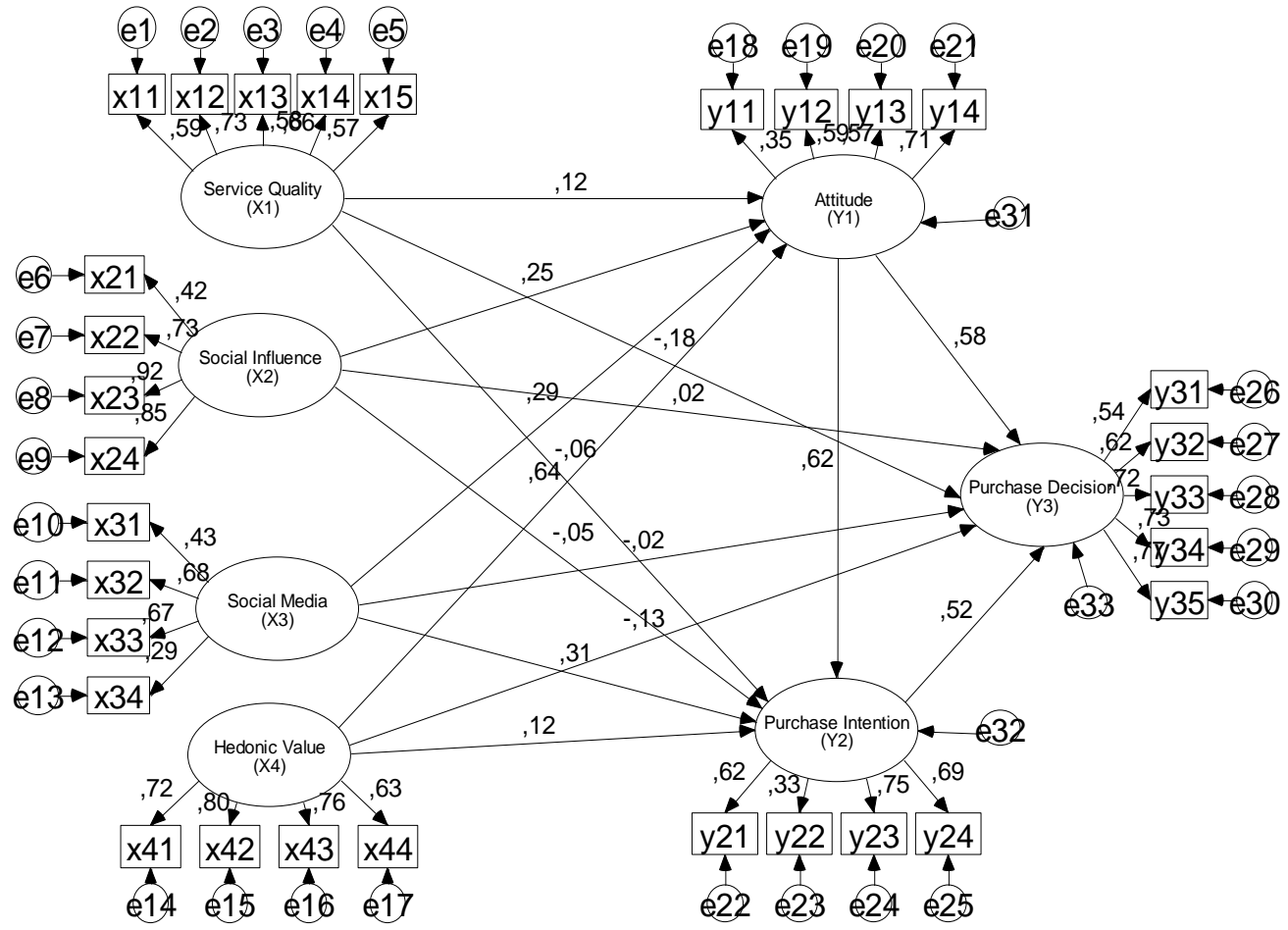

Fig. 1. The results of the structural model 
The biggest loading factor value of the Service Quality variable is the Reliability indicator with a value or weight of 0.728 greater than the error term value, namely 0.5 , which means that the Service Quality variable is reflected in the Reliability indicator. It shows that the Reliability indicator has a level of truth as a measure of the Service Quality variable of 73\% and the affected variable is the Purchase Intention variable which is reflected in the Will Buy indicator with a value or weight of 0.754 greater than the error term value of 0.5. It shows that the Will Buy indicator has a level of truth as a measure of the Purchase Intention variable by $75 \%$. Service Quality variable which is reflected in the Reliability indicator does not have a significant effect on the Purchase Intention variable which is reflected in the Will Buy indicator. This means that the quality of service for employee consistency in providing services to Cinema XXI visitors cannot affect visitors 'interest in visitors' willingness to watch at Cinema XXI.

Based on the results of the calculation of the path coefficient between Service Quality and Purchase Decision, it shows a significant effect with a negative direction of -0.194, which means that the level of closeness or strength of the relationship between Service Quality and Purchase Decision variables is $19 \%$. Based on the results of the statistical test, the value of the Critical Ratio (CR) variable of Service Quality to Purchase Intention is -2.089, which is greater than the critical value of \pm 1.96 which is determined from the t table if a study uses more than 100 respondents. Significant results can also be seen from the probability value ( $p$-value) of 0.037 which is smaller than the error rate $(\alpha)$ which is set at $5 \%$ and 0.05 . This shows that Service Quality has a significant negative effect on Purchase Decision for Cinema XXI. This means that the higher the quality of service provided by Cinema XXI, the less impact it will have on the decision to watch Cinema XXI.

The biggest loading factor value of the Service Quality variable is the Reliability indicator with a value or weight of 0.728 greater than the error term value, namely 0.5 , which means that the Service Quality variable is reflected in the Reliability indicator. It shows that the Reliability indicator has a level of truth as a measure of the Service Quality variable by $73 \%$ and the affected variable is the Purchase Decision variable which is reflected in the Post Purchase Behavior indicator with a value or weight of 0.767 greater than the error term value, namely 0.5 . It shows that the Post Purchase Behavior indicator has a level of truth as a measure of the Purchase Decision variable by $77 \%$. Service Quality variable which is reflected in the Reliability indicator has a significant effect on the Purchase Decision variable which is reflected in the Post Purchase Behavior indicator. This means that the quality of service for the consistency of employees in providing services to Cinema XXI visitors can influence a person's decision to be able to watch again at Cinema XXI.

Social Influence on Attitude shows a significant influence with a positive direction of 0.215 , which means that the level of closeness or the relationship between the Social Influence variable on Attitude is $12 \%$. Based on the results of the statistical test the value of the Critical Ratio (CR) of the Social Influence variable on Attitude is 2.076, which is greater than the critical value of \pm 1.96 which is determined from the $t$ table if a study uses more than 100 respondents. Significant results can also be seen from the probability value ( $\mathrm{p}$ value) of 0.038 which is greater than the error rate $(\alpha)$ which is set at $5 \%$ and 0.05 . This shows that Social Influence has a significant positive effect on the Attitude at XXI Cinemas.

Social influence on Purchase Intention shows an insignificant influence with a negative direction of -0.057 , which means that the level of closeness or strength of the relationship between the Social Influence variable on Purchase Intention is 6\%. Based on the results of the statistical test the value of the Critical Ratio (CR) of the Social Influence variable on Purchase Intention is -0.533 smaller than the critical value \pm 1.96 which is determined from the $t$ table if uses more than 100 respondents. The insignificant results can also be seen from the probability 
value. (p-value) of 0.594 which is greater than the error rate $(\alpha)$ which is set at $5 \%$ and 0.05 . This shows that Social Influence has a negative and insignificant effect on Purchase Intention for Cinema XXI. It is means that someone's social influence because they often consult friends or family has little influence on someone to raise the intention to be willing to watch Cinema XXI.

Based on the results of the calculation of the path coefficient between social influence on Purchase Decision, it shows an insignificant influence with a positive direction of 0.016, which means that the level of closeness or strength of the relationship between the Social Influence variable on Purchase Decision is $2 \%$. Based on the results of the statistical test, the Critical Ratio (CR) value of the Social Influence variable on Purchase Decision is 0.196 smaller than the critical value \pm 1.96 which is determined from the $t$ table if a study uses more than 100 respondents. The insignificant results can also be seen from the probability value ( $\mathrm{p}$-value) of 0.845 which is greater than the error rate $(\alpha)$ which is set at $5 \%$ and 0.05 . This shows that Social Influence has a positive and insignificant effect on the Purchase Decision variable for Cinema XXI visitors.

Strength of the relationship between the Social Media variable to Attitude is $28 \%$. Based on the results of the statistical test, the value of the Critical Ratio (CR) of the Social Media variable to the Attitude variable is 2,076 , greater than the critical value of \pm 1.96 . which is determined from the $t$-table if a study uses the number of respondents more than 100 . Significant results can also be seen from the probability value (p-value) of 0.045 which is greater than the error rate $(\alpha)$ which is determined at $5 \%$ and 0.05 . This shows that the Social Media variable has a significant positive effect on the Attitude variable.

Based on the results of the calculation of the path coefficient between social media and Purchase Intention, it shows a significant influence with a positive direction of 0.376 , which means the level of closeness or strength of the relationship between Social Media variables on Purchase Intention is $38 \%$. Based on the results of the statistical test, the Social Media variable's Critical Ratio (CR) value to the Purchase Intention variable is 2.161 , which is greater than the critical value of \pm 1.96 . which is determined from the t-table if a study uses the number of respondents more than 100 . Significant results can also be seen from the probability value (pvalue) of 0.031 which is greater than the error rate $(\alpha)$ which is determined at $5 \%$ and 0.05 . This shows that the Social Media variable has a significant positive effect on the Purchase Intention variable.

Based on the results of the calculation of the path coefficient between social media and Purchase Decision, it shows an insignificant influence with a negative direction of -0.025 , which means the level of closeness or strength of the relationship between Social Media variables to Purchase Decision is $2 \%$. Based on the results of the statistical test the value of the Critical Ratio (CR) of the Social Media variable to the Purchase Decision variable is -0.190 , smaller than the critical value of \pm 1.96 . which is determined from the $t$ table if a study uses the number of respondents more than 100 . The insignificant results can also be seen from the probability value (p-value) of 0.849 which is greater than the error rate $(\alpha)$ which is determined at $5 \%$ and 0.05 . This shows that the Social Media variable has a negative and insignificant effect on the Purchase Decision.

The results of the calculation of the path coefficient between the Hedonic Value on Attitude, it shows a significant effect with a positive direction of 0.428 , which means that the level of closeness or strength of the relationship between the Hedonic Value and Attitude variables is $49 \%$. Based on the statistical test results, the value of the Critical Ratio (CR) of the Hedonic Value variable to the Attitude variable is 3,311 , which is greater than the critical value of \pm 1.96 . which is determined from the $t$ table if a study uses the number of respondents more than 
100.The insignificant results can also be seen from the probability value (p-value) of *** $(0.000)$ which is smaller than the error rate $(\alpha)$ which is determined by $5 \%$ and 0.05 . This shows that the Hedonic Value variable has a significant positive effect on the Attitude variable. It means that the visitor's decision to watch Cinema XXI is influenced by the hedonic. This confirms the theory put forward by Lombardi et. al. [3] which states that there is a significant relationship between the Hedonic Value variable and the Attitude variable.

Based on the results of the calculation of the path coefficient between Hedonic Value and Purchase Decision, it shows an insignificant influence with a positive direction of 0.102 , which means the level of closeness or strength of the relationship between the Hedonic Value variable to Purchase Intention is $1 \%$. Based on the statistical test results, the value of the Critical Ratio (CR) of the Hedonic Value variable on the Purchase Decision variable is 0.729, smaller than the critical value of \pm 1.96 . which is determined from the $t$ table if a study uses the number of respondents more than 100 . The insignificant results can also be seen from the probability value (p-value) of 0.466 which is greater than the error rate $(\alpha)$ which is determined at $5 \%$ and 0.05 . This shows that the Hedonic Value variable has a positive and insignificant effect on the Purchase Intention variable. This means that a respondent's interest in visiting Cinema XXI is not influenced by the respondent's hedonic value.

Based on the results of the calculation of the path coefficient between Hedonic Value and Purchase Decision, it shows an insignificant effect in a negative direction with a value of -0.099, which means the level of closeness or strength of the relationship between the Hedonic Value variable to Purchase Decision is $1 \%$. Based on the results of the statistical test, the value of the Critical Ratio (CR) variable Hedonic Value to the Purchase Decision variable is -0.927 smaller than the critical value \pm 1.96 which is determined from the $t$ table if a study uses more than 100 respondents. The insignificant results can also be seen from the value probability (p-value) of 0.354 which is greater than the error rate $(\alpha)$ which is set at $5 \%$ and 0.05 . This shows that Hedonic Value has a negative and insignificant effect on Purchase Decision for Cinema XXI. This means that the respondent's decision to watch Cinema XXI is not influenced by the hedonic value of visiting Cinema XXI.

Based on the results of the calculation of the path coefficient between Attitude and Purchase Intention, it shows a significant effect with a positive direction of 0.767 , which means that the level of closeness or strength of the relationship between Attitude and Purchase Intention variables is $77 \%$. Based on the statistical test results, the value of the Critical Ratio (CR) of the Attitude variable against the Purchase Intention variable is 2,349, which is greater than the critical value of \pm 1.96 . which is determined from the $t$ table if a study uses the number of respondents more than 100 . Significant results can also be seen from the probability value (pvalue) of 0.019 which is smaller than the error rate $(\alpha)$ which is determined at $5 \%$ and 0.05 . This shows that the Attitude variable has a significant positive effect on the Purchase Intention variable. Which means that someone's interest in visiting Cinema XXI, is influenced by the attitude of visitors watching at Cinema XXI.

The loading factor value of the Attitude variable is the Better Choice indicator with a value or weight of 0.711 which is greater than the error term, namely 0.5 , which means that the Attitude variable is reflected in the Better Choice indicator. It shows that the Better Choice indicator has a level of truth as a measure of the Attitude variable of $71 \%$, and the variable affected is the Purchase Intention variable which is reflected in the Will Buy indicator with a value or weight of 0.754 greater than the error term value of 0.5 . It shows that the Will Buy indicator has a level of truth as a measure of the Purchase Intention variable by $75 \%$.

Based on the calculation of the path coefficient between Attitude and Purchase Decision, it shows a significant effect in a positive direction with a coefficient value of 0.685 , which means 
that the level of closeness or strength of the relationship between Attitude and Purchase Decision variables is $69 \%$. Based on the statistical test results, the value of the Critical Ratio (CR) variable Attitude to Purchase Decision is 2.031, greater than the critical value of \pm 1.96 and a significant probability (p) of 0.042 is obtained which is smaller than the error rate $(\alpha)$ which is determined at 0.05. This shows that Attitude has a significant positive effect on Purchase Decision for visitors to Cinema XXI. This means that the higher one's interest in watching Cinema XXI, it will affect one's decision to watch Cinema XXI.

The calculation of the path coefficient between Purchase Intention and Purchase Decision, it shows a significant effect with a positive direction of 0.496 , which means that the level of closeness or strength of the relationship between Purchase Intention and Purchase Decision variables is $50 \%$. Based on the statistical test results, the Critical Ratio (CR) value of the Purchase Intention variable to the Purchase Decision variable is 2,365, greater than the critical value of \pm 1.96 . Significant results can also be seen from the probability value (p-value) of 0.018 which is smaller than the error rate $(\alpha)$ which is set at $5 \%$ and 0.05 . This shows that the Purchase Intention variable has a significant positive effect on the Purchase Decision variable. Which means that a person's decision to visit Cinema XXI, is influenced by one's interest in visiting Cinema XXI.

\section{References}

[1] Kotler, P., \& Armstrong, G. (2018). Principle of Marketing (17th ed.). London, United Kingdom: Pearson Education.

[2] Kotler, P., \& Keller, K. L. (2009). Marketing Management (13th Edition). New Jersey: Pearson Education, Inc.

[3] Lombardi, A., Carfora, V., Cicia, G., Giudice, T., Lombardi, P., \& Panico, T. (2017). Exploring Willingness to Pay for QR Code Labeled ExtraVirgin Olive Oil: An Application of the Theory of Planned Behavior. Int. J. Food System Dynamics 8 (1), 14-31.

[4] Lovelock, C. H., \& Gummesson. (2011). Pemasaran Jasa (7th ed.). Jakarta: Erlangga.

[5] Somba, W. E., Sunaryo, \& Mugiono. (2018). Pengaruh Nilai Hedonis Dan Nilai Utilitarian Terhadap Behavioral Intention Dengan Word Of Mouth (Wom) Sebagai Variabel Mediasi . jurnal manajemen dan kewirausahaan vol 6, no. 1. 2018., 82-92.

[6] SWidyastuti, S., Prasetyo, H., \& Gustari, I. (2017). An Investigating on the Purchase Intention: Developing Dealers Reputation through Customer Trust and Service Quality. European Journal of Social Sciences, 316-331.

[7] Wiridjati, W., \& Risqiani, R. (2018). Fenomena Penggunaan Media Sosial Dan Pengaruh Teman Sebaya Pada Generasi Milenial Terhadap Keputusan Pembelian. Jurnal Manajemen dan Pemasaran Jasa Vol. 11 No. 2 September 2018, 275-290.

[8] Yulianto, Edy, Astuti, S., Endang, Suyadi, Imam, et al. (2014). The Effect of Online Service Quality towad Perceived Risk, Customer Attitudes, Relationship Quality, Online Purchase Intention, ELoyalty, and Purchasing Behavior. European Journal of Business and Management Vol.6, No.22, 2014, 89-97. 